\title{
A natural food aversion in rats rendered hyperphagic by hypothalamic knife cuts
}

\author{
STEPHEN L. ANTHONY and W. J. CARR \\ Beaver College, Glenside, Pennsylvania
}

\begin{abstract}
Eight hungry rats previously rendered hyperphagic via hypothalamic parasagittal knife cuts did not differ reliably from eight sham-operated controls in their tendencies to feed upon the intact carcasses of freshly sacrificed conspecifics. The ventromedial hypothalamus is not an essential link in the neural circuit mediating the aversion of rats to feed on conspecific flesh.
\end{abstract}

Hungry Norway rats exhibit an aversion to feed on conspecific flesh in the sense that, during a 1-h test, a large majority remain hungry rather than feed on a dead conspecific, whereas a large majority feed on a dead nonconspecific (e.g., a roof rat, Rattus rattus) rather than remain hungry (Carr, Landauer, Wiese, Marasco, $\&$ Thor, 1979). The aversion is mediated, at least in part, by the same chemical signals from the dead rat's furry coat that also mediate species-recognition (Carr, Dissinger, \& Scannapieco, 1982; Carr, Hirsch, Campellone, \& Marasco, 1979). Moreover, the tendency of rats to reject conspecific flesh stems ontogenetically from previous experience with conspecifics, and with their own bodies (Carr, Choi, Arnholt, \& Sterling, 1983).

The present experiment represents an initial attempt to identify the neural mechanisms that mediate this food aversion, which is known to be influenced by experiential factors (Carr et al., 1983). During a 2-h test, we compared the tendencies of two groups of hungry rats to feed on the intact carcasses of freshly sacrificed adult conspecifics. Prior to testing, one group had been rendered hyperphagic via hypothalamic knife cuts. The other group received sham operations. Our experiment was prompted by earlier research that yielded conflicting findings with regard to the effect of hypothalamic insult on the acquisition of learned food aversions (Bureš \& Burešová, 1977).

\section{METHOD}

\section{Subjects and Donors}

Sixteen male rats served as subjects, and 16 males served as donors (i.e., as animals that were sacrificed and offered to subjects as food). All of the rats were born in our laboratory of Long-Evans stock (Perfection Breeders, Douglassville, Pennsylvania). They were reared from weaning until 12-14 weeks of age in groups of 3 or 4 in hardware-cloth cages $(25 \times 40 \times 70 \mathrm{~cm})$ lined with pinewood-chip bedding. Throughout the experiment, the animals lived in temperature-controlled rooms $\left(21^{\circ}-22^{\circ} \mathrm{C}\right)$

The surgery was performed by one of us (S.A.) at the School of Veterinary Medicine of the University of Pennsylvania. We thank Richard Miselis for his help and encouragement. Requests for reprints should be addressed to W. J. Carr, Department of Psychology, Beaver College, Glenside, Pennsylvania 19038. on a 12-h:12-h light:dark cycle. They had constant access to lab-chow pellets (Zeigler RQ) and water, except as noted below.

\section{Procedure and Apparatus}

Surgery and postoperative treatment. At 12-14 weeks of age, eight subjects were selected randomly and rendered hyperphagic by a stereotaxic technique described in detail by Gold (1970). While under general anesthesia (Chloropent, $3 \mathrm{mg} / \mathrm{kg}$ ip), these subjects received parasagittal knife cuts that bilaterally severed the neural pathways connecting the ventromedial nuclei and the lateral nuclei of the hypothalamus. The remaining subjects received the same surgical treatment, except that the knife cuts were not made.

Immediately following surgery, the subjects were housed individually in translucent plastic cages $(12 \times 22 \times 35 \mathrm{~cm})$ lined with pinewood chips and covered with wire lids. The animals were weighed daily for 4 consecutive weeks to determine whether those that had received hypothalamic knife cuts exhibited the sharp increase in body weight that is characteristic of hyperphagic animals. During the 4-week period, the mean body weight of the animals that had received knife cuts increased from 453 to $516 \mathrm{~g}$, whereas the controls increased from 436 to $460 \mathrm{~g}$. The difference between the two groups in weight gain is statistically reliable [Mann-Whitney $\mathrm{U}$ test, $\mathrm{U}(8,8)=1, \mathrm{p}<.01$ ] We infer that the rats that had received hypothalamic lesions were hyperphagic.

Deprivation schedule and feeding test. Beginning 10 days before the feeding test, each subject received $60 \mathrm{~g}$ of powdered lab chow for $1 \mathrm{~h} /$ day. At 18-20 weeks of age, each subject received a single 2 - $h$ feeding test, conducted in its home cage after the subject had been food deprived for $23 \mathrm{~h}$. At the outset of the test, the subject was offered an intact donor positioned on its side in the center of the cage. From behind a one-way viewing screen located about $80 \mathrm{~cm}$ from the cage, the experimenters recorded the latency to begin feeding. Feeding was said to occur when the subject pierced the donor's skin or removed a digit.

Rats that have been rendered hyperphagic via hypothalamic insult sometimes do not work as hard to gain food as do normal rats (Teitelbaum, 1957). In the present experiment, the donor's tough furry coat may have impeded feeding, more so among the hyperphagic subjects than among the controls. Therefore, if the subjects did not feed on their donor within the 1st hour, an incision was made in their donor's coat, beginning at the neck and extending $2 \mathrm{~cm}$ along the ventral midline. The incision penetrated the skin, leaving the fascia intact.

Donor preparation. The donors were sacrificed painlessly via a technique said to produce no histological changes in nonpulmonary tissue and only slight pulmonary effects (Stevens, Prince, \& Cummings, 1977). While still in their home cages, the donors were lowered into a large plastic bag containing $75 \%$ $85 \% \mathrm{CO}_{2}$. They appeared to be unconscious within $1 \mathrm{~min}$, and they were dead within $5 \mathrm{~min}$. The donors were weighed before 
Table 1

Feeding Behavior of Subjects Offered a Rat Donor During 2-h Test

\begin{tabular}{|c|c|c|c|c|c|}
\hline \multirow[b]{2}{*}{ Group } & \multirow[b]{2}{*}{$\mathrm{N}$} & \multicolumn{2}{|c|}{$\begin{array}{l}\text { Percentage } \\
\text { Feeding }\end{array}$} & \multirow{2}{*}{$\begin{array}{c}\mathrm{M} \\
\text { Feeding } \\
\text { Latency }\end{array}$} & \multirow{2}{*}{$\begin{array}{c}\text { M } \\
\text { Amount } \\
\text { Eaten }\end{array}$} \\
\hline & & $1-\mathrm{h}$ & $2-\mathrm{h}$ & & \\
\hline Hyperphagic & 8 & 37.5 & 50.0 & 76.1 & 3.2 \\
\hline Control & 8 & 12.5 & 50.0 & 91.9 & 7.8 \\
\hline
\end{tabular}

Note-Mean feeding latency given in minutes; subjects not feeding were assigned a feeding latency of $120 \mathrm{~min}$. Mean amount eaten is given in grams.

and after testing to determine the amount of tissue consumed. The elapsed time between their deaths and the onset of testing was 10-15 min. No donor had ever been caged with any of the subjects.

\section{RESULTS AND DISCUSSION}

Table 1 shows the performance of the two groups of subjects during the $2 \cdot h$ feeding test. The hyperphagic subjects did not differ reliably from the controls with respect to the proportion that fed on their donors, the latency to begin feeding, or the amount of tissue consumed. Therefore, we infer that the ventromedial hypothalamus is not an essential link in the neural circuit that controls the aversion of rats to feed on conspecific flesh.

The aversion of hungry rats to feed on conspecific flesh is mediated, at least in part, by the same chemical signals by which rats recognize one another as conspecifics (Carr et al., 1982; Carr, Hirsch, et al., 1979; Carr, Landauer, et al., 1979). Moreover, the aversion also depends upon experiential factors (Carr et al., 1983). Therefore, additional research may implicate neural mechanisms that control social behavior, especially species recognition (MacLean, 1973; Roy, 1980) or mechanisms that control acquired food aversions (Braun, Kiefer, \& Ouellet, 1981; Lasiter \& Glanzman, 1982).

\section{REFERENCES}

Braun, J. J., Kiefer, S. W., \& Ouellet, J. V. Psychic ageusia in rats lacking gustatory neocortex. Experimental Neurology, - 1981, 72, 711-716.

Bureš, J., \& Burešová, O. Physiological mechanisms of conditioned food aversion. In N. W. Milgram, L. Krames, \& T. M. Alloway (Eds.), Food aversion learning. New York: Plenum, 1977.

Carr, W. J., Choi, S. Y., Arnholt, E., \& Sterling, M. H. The ontogeny of a natural food aversion in domestic rats (Rattus norvegicus) and house mice (Mus musculus). Journal of Comparative Psychology, 1983, 97, 280-288.

Carr, W. J., Dissinger, M. L., \& Scannapieco, M. R. The stimulus-basis of a natural food aversion in Norway rats. Physiology \& Behavior, 1982, 28, 281-287.

Carr, W. J., Hirsch, J. T., Campellone, B. E., \& Marasco, E. Some determinants of a natural food aversion in Norway rats. Journal of Comparative and Physiological Psychology, 1979, 93, 899-903.

Carr, W. J., Landauer, M. R., Wiese, R. E., Jr., Marasco, E., \& THOR, D. H. A natural food aversion in Norway rats. Journal of Comparative and Physiological Psychology, 1979, 93, 574-584.

GoLD, R. M. Hypothalamic hyperphagia produced by parasagittal knife cuts. Physiology \& Behavior, 1970, 5, 23-25.

Lasiter, P. S., \& Glanzman, D. L. Cortical substrates of taste aversion learning: Dorsal prepiriform (insular) lesions disrupt taste aversion learning. Journal of Comparative and Physiological Psychology, 1982, 96, 376-392.

MacLean, P. D. A triune concept of the brain and behavior. Toronto: University of Toronto Press, 1973.

Roy, M. A. An introduction to the concept of species identity. In M. A. Roy, (Ed.), Species identity and attachment. New York: Garland, 1980.

Stevens, J. D., Prince, M. D., \& Cummings, J. F. Euthanasia chambers: Are yours safe and inexpensive? Lab Animal, 1977, 6, 39-42.

Teitelbaum, P. Random and food-directed activity in hyperphagic and normal rats. Journal of Comparative and Physiological Psychology, 1957, 50, 486-490.

(Manuscript received for publication May 28, 1983.) 